\title{
Pengaruh Beban Kerja terhadap Kinerja Karyawan PT. Bank Rakyat Indonesia (persero) Tbk Cabang Krekot
}

\author{
Yudha Adityawarman \\ Program Pascasarjana Manajemen dan Bisnis \\ Institut Pertanian Bogor \\ Kampus MB IPB Padjajaran Bogor \\ e-mail: yudha.adityawarman@gmail.com \\ Bunasor Sanim \\ Program Pascasarjana Manajemen dan Bisnis \\ Institut Pertanian Bogor \\ Kampus MB IPB Padjajaran Bogor
}

Bonar M Sinaga

Departemen Ekonomi Sumberdaya dan Lingkungan, Fakultas Ekonomi dan Manajemen Institut Pertanian Bogor

Kampus Darmaga Bogor 16680

\begin{abstract}
The workload is very important for a company. By administering an effective workload, a company can determine how much maximum workload can be given to its employees and how big is the influence on the performance of the company itself. The purpose of this study was to determine the influence of workload on employee performance of Bank Rakyat Indonesia (Persero) Tbk Krekot Branch. Data were obtained from 127 respondents, then chi-square test was used to determine the respondent's perception of variable workload and performance based on demographic factors. The results of chisquare test shows that there was a difference of perception based on demographics of the respondents. Spearman rank analysis results shows that the workload is correlated with performance variables, while for the other variables are mutually correlated, but the correlation is low. To determine the influence of workload on the performance of employees of Bank Rakyat Indonesia (Persero) Tbk Krekot Branch, Structural Equation Modelling Method with Partial Least Square (PLS) is used. The results of the analysis reveal that the workload is positively and significantly influenced the performance of Bank Rakyat Indonesia (Persero) Tbk Krekot Branch employees at the 5\% level of significance ( $p=0.10882)$; thus, the initial hypothesis is accepted.

Keywords: workload, employee performance, Bank Rakyat Indonesia (Persero) Tbk, linfluence, Bank Rakyat Indonesia (Persero) Tbk Krekot Branch
\end{abstract}

\begin{abstract}
ABSTRAK
Beban kerja sangat penting bagi sebuah perusahaan. Dengan pemberian beban kerja yang efektif perusahaan dapat mengetahui sejauh mana karyawannya dapat diberikan beban kerja yang maksimal dan sejauh mana pengaruhnya terhadap kinerja perusahaan itu sendiri. Tujuan dari penelitian ini adalah untuk mengetahui pengaruh beban kerja terhadap kinerja karyawan PT. Bank Rakyat Indonesia (persero) Tbk Cabang Krekot. Data diperoleh dari 127 responden, uji chi square digunakan untuk mengetahui sikap responden terhadap variabel beban kerja dan kinerja berdasarkan faktor demografik. Hasil uji chi square menunjukan adanya perbedaan sikap berdasarkan demografik responden. Hasil analisis rank spearman menunjukan bahwa variabel beban kerja memiliki korelasi dengan variabel
\end{abstract}


kinerja, sementara untuk sub variabel lainnya saling memiliki korelasi namun tingkat korelasinya rendah. Untuk mengetahui pengaruh beban kerja terhadap kinerja kerja karyawan PT. Bank Rakyat Indonesia (persero) Tbk Cabang Krekot digunakan teknik analisis statistika Structural Equation Modelling berbasis variance dengan Metode Partial Least Square (PLS), hasil analisis menunjukan bahwa beban kerja berpengaruh positif dan signifikan secara langsung terhadap kinerja karyawan PT. Bank Rakyat Indonesia (persero) Tbk Cabang Krekot pada tingkat signifikansi 5\% ( $p=0.10882$ ), maka hipotesis awal terima Ho dengan thitung 13.45 lebih besar dari t tabel 1.96

Kata kunci: beban kerja, kinerja karyawan, Bank Rakyat Indonesia (persero) Tbk, pengaruh, PT. Bank Rakyat Indonesia (persero) Tbk Cabang Krekot

\section{Pendahuluan}

Manusia merupakan aset utama dalam organisasi, sehingga sumber daya manusia (SDM) harus dikelola dan dimanfaatkan secara seimbang dan manusiawi. Bandar dan Manar (2012) mengatakan bahwa sudah merupakan hal yang umum SDM merupakan aset terbesar bagi organisasi. Sedangkan Cao dan Yu (2007) mendefinisikan SDM mengacu pada kemampuan pekerja yang mempromosikan pembangunan ekonomi dan sosial secara keseluruhan, termasuk kemampuan kerja intelektual dan kerja fisik. SDM bukan berarti hanya merujuk kepada manusianya saja tetapi kemampuan si karyawan tersebut, Khadijeh dan Sumangala (2013) memberi pendapat bahwa bakat, kompetensi, ide, energi dari karyawan, produktivitas, dan kinerja dari organisasi secara kolektif diidentifikasikan sebagai SDM dari sebuah perusahaan.

Sesuai dengan visi PT. Bank Rakyat Indonesia (persero) Tbk yaitu menjadi bank komersial terkemuka yang selalu mengutamakan kepuasan nasabah, PT. Bank Rakyat Indonesia (persero) Tbk selalu melakukan eskpansi bisnis bersamaan dengan peningkatan pelayanan kepada nasabah dalam berbagai bidang layanan perbankan, baik berupa layanan operasional maupun e-banking. Sebagai wujud ekspansi bisnis dari PT. Bank Rakyat Indonesia (persero) Tbk, maka setiap tahunnya PT. Bank Rakyat Indonesia (persero) Tbk Cabang Krekot diberikan target yang lebih tinggi minimal melampaui pencapaian kinerja ditahun sebelumnya. Untuk mencapai target tersebut, maka diperlukan penerapan strategi SDM yang tepat. Malik (2009) berpendapat bahwa penerapan strategi SDM yang tepat akan memunculkan kemampuan untuk mendorong proses kreasi praktik-praktik SDM yang lebih inovatif, progresif dan berkinerja tinggi. Untuk mendukung penerapan strategi SDM yang tepat dibutuhkan manajemen sumber daya manusia yang baik. Manajemen sumber daya manusia merupakan salah satu faktor yang sangat penting untuk keberhasilan bisnis. Tanpa itu, tidak ada visi yang jelas, dan kesempatan akan tersia-siakan (Akbar 2013).

Tabel 1. Rencana kinerja anggaran PT. Bank Rakyat Indonesia (persero) Tbk Cabang Krekot

\begin{tabular}{clccccc}
\hline \multirow{2}{*}{ No } & \multicolumn{1}{c}{$\begin{array}{c}\text { Materi } \\
\text { Anggaran }\end{array}$} & $\begin{array}{c}\text { Posisi } \\
\text { 31-Dec-13 } \\
\text { Nominal }\end{array}$ & $\begin{array}{c}\text { P1-Dec-14 } \\
\text { RKA }\end{array}$ & $\begin{array}{c}\text { Posisi } \\
\text { Nominal } \\
\text { Nominal }\end{array}$ & $\begin{array}{c}\text { Posisi } \\
\text { 28-Feb-14 } \\
\text { Nominal }\end{array}$ & $\begin{array}{c}\text { Posisi-Mar-14 } \\
\text { Nominal }\end{array}$ \\
\hline \multirow{2}{*}{ 1 } & Dana / Simpanan & 6501739 & 7853404 & 6259969 & 6124344 & 6670853 \\
& 1. Giro & 657084 & 1331508 & 543291 & 571954 & 691474 \\
& 2. Tabungan & 183583 & 336542 & 174323 & 171663 & 158491 \\
& 3. Deposito & 5661072 & 6185354 & 5542355 & 5380727 & 5820888 \\
& Total Kanca & 6399920 & 7730413 & 6165370 & 6024301 & 6569151 \\
\hline \multirow{2}{*}{2} & Total Pinjaman & 523884 & 615858 & 514827 & 522781 & 529886 \\
& 1. NPL (Rp) & 3709 & 5498 & 3233 & 11103 & 6299 \\
& 2. NPL (\%) & $0.71 \%$ & $0.89 \%$ & $0.63 \%$ & $2.12 \%$ & $1.19 \%$ \\
\hline
\end{tabular}


36|Adityawarman, Sanim, Sinaga - Pengaruh Beban Kerja terhadap Kinerja Karyawan

Lanjutan Tabel 1.

\begin{tabular}{|c|c|c|c|c|c|c|c|}
\hline No & $\begin{array}{c}\text { Materi } \\
\text { Anggaran }\end{array}$ & $\begin{array}{c}\text { Posisi } \\
\text { 30-Apr- } \\
14 \\
\text { Nominal }\end{array}$ & $\begin{array}{c}\text { Posisi } \\
\text { 9-May-14 } \\
\text { Nominal }\end{array}$ & $\begin{array}{c}\text { Delta } \\
\text { 30-Apr-14 } \\
\text { 9-May-14 }\end{array}$ & $\begin{array}{c}\text { Delta } \\
\text { 31-Dec- } \\
13 \\
\text { 9-May-14 }\end{array}$ & $\begin{array}{c}\text { RKA } \\
\text { Target } \\
\text { 30-Apr-14 }\end{array}$ & $\begin{array}{c}\text { Pencapaian } \\
\text { (\%) } \\
\text { 30-Apr-14 }\end{array}$ \\
\hline \multirow{5}{*}{1} & $\begin{array}{l}\text { Dana / } \\
\text { Simpanan }\end{array}$ & 6707945 & 6459706 & (248 239) & (42 033) & 270333 & -16 \\
\hline & 1. Giro & 1007035 & 549819 & (457 216) & (107 265) & 134885 & -80 \\
\hline & 2. Tabungan & 158814 & 161381 & 2567 & $(22$ 202) & 30592 & -73 \\
\hline & 3. Deposito & 5542096 & 5748506 & 206410 & 87434 & 104856 & 83 \\
\hline & Total Kanca & 6610876 & 6365414 & $(245462)$ & (34 506) & 266099 & -13 \\
\hline \multirow{3}{*}{2} & Total Pinjaman & 534971 & 521802 & $(13$ 169) & $(2082)$ & 18395 & 11 \\
\hline & 1. NPL (Rp) & 5334 & 7973 & 2639 & 4264 & 5498 & 87 \\
\hline & 2. NPL (\%) & $1.00 \%$ & $1.53 \%$ & 0 & 0 & 0 & 2219 \\
\hline
\end{tabular}

Sumber: PT. Bank Rakyat Indonesia (persero) Tbk Cabang Krekot (2014)

Pada Tabel 1 di atas dapat dilihat Rencana Kinerja Anggaran (RKA) PT. Bank Rakyat Indonesia (persero) Tbk Cabang Krekot di tahun 2014 belum ada yang mencapai target terkecuali target NPL yang telah memenuhi target, sedangkan target dana simpanan maupun pinjaman masih belum mencapai target.

Pertambahan target RKA bukan hanya semata-mata beban dari marketing saja, melainkan beban seluruh karyawan PT. Bank Rakyat Indonesia (persero) Tbk Cabang Krekot. Sebagai contoh ketika seorang marketing mendapatkan nasabah baik itu nasabah pinjaman ataupun nasabah simpanan maka dari bagian marketing akan memberikan berkas aplikasi pembukaan rekening untuk di buatkan rekening oleh bagian operasional. Khusus nasabah pinjaman saat rekeningnya dibuat oleh bagian operasional secara paralel, maka bagian administrasi kredit (ADK) mengurus semua yang dibutuhkan dalam hal legalitas hukum. Dengan demikian, secara keseluruhan jika beban kerja seorang marketing bertambah, maka beban kerja karyawan lain juga ikut bertambah. Pengertian beban kerja menurut Menpan (1997), adalah sekumpulan atau sejumlah kegiatan yang harus diselesaikan oleh suatu unit organisasi atau pemegang jabatan dalam jangka waktu tertentu.

Bertambahnya target yang harus dicapai PT. Bank Rakyat Indonesia (persero) Tbk Cabang Krekot maka, bertambah pula beban karyawannya, menurut Setyawan dan Kuswati (2006) apabila beban kerja terus menerus bertambah tanpa adanya pembagian beban kerja yang sesuai maka kinerja karyawan akan menurun. Kinerja menurut Simamora (2001) adalah proses dengannya organisasi mengevaluasi pelaksanaan kerja individu. Ada beberapa faktor yang mempengaruhi kinerja karyawan menurut Mangkuprawira dan Mangkuprawira dan Hubeis (2007), yaitu :

1. Faktor Instrinsik

Faktor personal atau individual yaitu pengetahuan, keterampilan (skill), kemampuan, kepercayaan diri, motivasi, dan komitmen yang dimiliki oleh tiap individu karyawan

2. Faktor Ekstrinsik

a. Faktor kepemimpinan, meliput iaspek mutu manajer dan team leader dalam memberikan dorongan, semangat, arahan dan dukungan kerja pada karyawan.

b. Faktor tim, meliputi aspek dukungan semangat yang diberikan oleh rekan dalam satu tim, kepercayaan terhadap anggota tim, kekompakan dan keeratan dalam anggota tim. 
c. Faktor sistem, meliputi sistem kerja, fasilitas kerja atau infrastruktur, yang diberikan oleh proses organisasi dan kultur kerja dalam organisasi.

d. Faktor situasional, meliputi tekanan dan perubahan internal dan eksternal.

Pada abad ke-21 manusia diakui sebagai sumber daya yang paling penting dari sebuah perusahaan (Katefina 2013) sehingga setiap organisasi memerlukan penilaian kinerja yang baik. Penilaian kinerja yang dilakukan akan memberikan manfaat bagi organisasi, di antaranya adalah mengetahui role clarity, kinerja pegawai, dan kepuasan kerja serta komitmen organisasi (Pettijohn dan Taylor2000).

Tujuan penelitian ini adalah untuk : 1) Menganalisis sikap karyawan PT. Bank Rakyat Indonesia (persero) Tbk Cabang Krekot tentang beban kerja dan kinerja; 2) Menganalisis korelasi beban kerja dan kinerja karyawan PT. Bank Rakyat Indonesia (persero) Tbk Cabang Krekot; 3) Menganalisis pengaruh beban kerja terhadap kinerja Karyawan PT. Bank rakyat Indonesia (persero) Tbk Cabang Krekot.

\section{Metode Penelitian}

Dalam penelitian ini digunakan metode deskriptif melalui pendekatan survei. Melalui penelitian ini, peneliti bermaksud memberikan gambaran secara rinci mengenai sikap responden terhadap beban kerja (pemberian beban kerja yang ada di PT. Bank Rakyat Indonesia (persero) Tbk Cabang Krekot) kondisi saat ini dan kondisi yang diharapkan oleh karyawan, dan hubungannya dengan kinerja karyawan. Hal ini dimaksudkan untuk memberikan informasi atau masukan kepada pihak PT. Bank Rakyat Indonesia (persero) Tbk Cabang Krekot tentang pemberian beban kerja yang dilaksanakan.

Data yang digunakan dalam penelitian ini berupa data primer dan data sekunder. Berikut susunan jenis data dan sumber data yang penulis ambil untuk penelitian ini dapat dilihat pada Tabel 2.

Tabel 2. Jenis dan sumber data

\begin{tabular}{clll}
\hline No. & \multicolumn{1}{c}{ Jenis Data } & \multicolumn{1}{c}{ Sumber Data } \\
\hline 1. & a. & Beban Kerja & Responden PT. Bank Rakyat Indonesia \\
& b. Kinerja & (persero) Tbk Cabang Krekot \\
2 & a. Penelitian Terdahulu & Jurnal, Artikel, Tesis, Skripsi \\
& b. Peraturan Pemerintah & Undang-undang No. 13 tahun 2003 \\
& c. Profil BRI Cabang Krekot & BRI Cabang Krekot \\
\hline
\end{tabular}

Untuk mendapatkan data yang diperlukan, maka penulis menggunakan beberapa macam cara untuk teknik pengumpulan data yang disesuaikan dengan judul penelitian ini. Menurut Dollyono (2008), teknik pengumpulan data itu antara lain :

1. Penelitian lapangan (Field Work Research), penelitian secara langsung ke lapangan atau objek penelitian untuk memperoleh data primer melalui metode survei. Penulis menggunakan daftar pertanyaan (kuisioner) yang terstruktur. Kuisioner itu diisi oleh responden secara tertulis mengenai beban kerja yang diberikan.

2. Penelitian kepustakaan (Library Research), penulis mengadakan orientasi dari berbagai informasi yang terdapat pada literatur yang berhubungan dengan permasalahan yang akan dibahas. 
3. Wawancara, pengumpulan data diperoleh secara langsung, mendalam, tidak terstruktur, individual langsung dengan responden dimana mereka akan ditanyai mengenai sikap, keyakinan, dan perasaan terhadap beban kerja yang diberikan.

4. Dokumentasi, pengumpulan data yang dimaksudkan untuk mendapatkan informasi mengenai gambaran perusahaan secara umum dan kebijakan pengembangan sumber daya manusia yang telah dijalankan oleh PT. Bank Rakyat Indonesia, Tbk.

Populasi dapat berupa organisasi, orang, benda, obyek, peristiwa, atau laporan. Populasi dalam penelitian ini adalah seluruh karyawan PT. Bank Rakyat Indonesia (persero) Tbk Cabang Krekot sebanyak 127 responden. Penelitian ini menggunakan seluruh populasi yang disebut metode sensus karena keterbatasan jumlah populasi maka diperlukan pengambilan sikap dari seluruh populasi karyawan PT. Bank Rakyat Indonesia (persero) Tbk Cabang Krekot agar dapat menangkap keragaman sikap berdasarkan faktor-faktor demografik usia dan pendidikan dan faktor-faktor non demografik jabatan dan golongan. Peningkatan keragaman sikap pegawai PT. Bank Rakyat Indonesia (persero) Tbk Cabang Krekotakan meningkatkan presisi data pada saat dilakukan dengan alat analisis Chi Square. Setelah didapatkan keragaman sikap responden berdasarkan faktor demografik maka dilakukan analisis Rank Spearman untuk mengetahui kedalaman pengaruh beban kerja terhadap kinerja.

Tabel 3. Populasi karyawan PT. Bank Rakyat Indonesia (persero) Tbk Cabang Krekot berdasarkan jabatan tahun 2013

\begin{tabular}{lcccccc}
\hline \multirow{2}{*}{ Pekerja } & Kanca & $\begin{array}{c}\text { KCP Pasar } \\
\text { Baru }\end{array}$ & $\begin{array}{c}\text { KCP Karang } \\
\text { Anyar }\end{array}$ & $\begin{array}{c}\text { Kantor } \\
\text { Kas BPS }\end{array}$ & $\begin{array}{c}\text { Kantor Kas } \\
\text { Asabri }\end{array}$ & Total \\
\hline PekerjaTetap & 27 & 3 & 3 & 1 & 1 & \\
Pekerja Kontrak & 23 & 4 & 4 & 2 & 2 & 1 \\
Pekerja Outsourcing & 47 & 4 & 4 & 1 & - & 127 \\
Job Trainee & - & - & - & - & 4 & 12 \\
Jumlah & 97 & 11 & 11 & 4 & & \\
\hline
\end{tabular}

Sumber : PT. Bank Rakyat Indonesia (persero) Tbk Cabang Krekot (2014)

Kuesioner yang terdiri dari beberapa butir pertanyaan yang disebarkan kepada karyawan diukur menggunakan skala Likert. Pengukuran dengan skala Likert adalah memberikan bobot tertentu pada setiap jawaban pertanyaan. Cara penilaian terhadap hasil kuisioner dapat dilihat pada Tabel 4.

Tabel 4. Skala likert dan bobot nilai jawaban responden

\begin{tabular}{clc}
\hline No & \multicolumn{1}{c}{ Kriteria } & Skor skala likert \\
\hline 1. & Sangat tidak setuju & 1 \\
2. & Tidak setuju & 2 \\
3. & Cukup setuju & 3 \\
4. & Setuju & 4 \\
5. & Sangat setuju & 5 \\
\hline
\end{tabular}

Sumber : Umar (2002)

Berdasarkan kerangka penelitian sebelumnya, maka penulis mengemukakan suatu hipotesis untuk identifikasi masalah dan tujuan penelitian sebagai berikut : Ho : Tidak terdapat hubungan variabel beban kerja dengan kinerja 
$\mathrm{H}_{\mathrm{a}} \quad$ : Terdapat hubungan variabel beban kerja dengan kinerja

\section{Hasil dan Pembahasan}

Untuk mengetahui status pertanyaan dalam daftar kuisoner apakah dapat dipergunakan sebagai alat penelitian, maka perlu diadakan uji validitas dan reliabilitas instrument. Menurut Nugroho (2005) uji validitas digunakan untuk mengetahui kelayakan butir-butir dalam suatu daftar (konstruk) pertanyaan dalam mendefinisikan suatu variabel. Kerangka konsep didefinisikan secara operasional, semua variabel baik variabel terikat maupun variabel bebas dijabarkan dalam bentuk item pertanyaanpertanyaan. Valid artinya data yang diperoleh dengan penggunaan alat (instrument) dapat menjawab tujuan penelitian.

III.1. Sikap Responden Berdasarkan Faktor Demografik terhadap Variabel Beban Kerja dan Kinerja

Salah satu pokok bahasan dalam penelitian ini adalah untuk mengetahui bagaimana sikap karyawan PT. Bank Rakyat Indonesia (persero) Tbk Cabang Krekot berdasarkan demografik terhadap variabel beban kerja dan kinerja apakah terdapat perbedaan respon dengan tingkat signifikansi sebesar 5\%. Sikap karyawan berdasarkan jenis kelamin menunjukkan adanya perbedaan sikap antara pria dan wanita mengenai tantangan organisasi, karyawan pria menyikapi tantangan organisasi berbeda dengan wanita sehingga kinerja karyawan pria berbeda dengan karyawan wanita.

Tabel 5. Sikap responden berdasarkan jenis kelamin

\begin{tabular}{clccc}
\hline Faktor & \multicolumn{1}{c}{ Kriteria } & $\begin{array}{c}\text { Tingkat } \\
\text { Signifikansi }\end{array}$ & Keputusan & Kesimpulan \\
& Tuntutan Kerja & 0.793 & Terima Ho & Tidak Ada Perbedaan \\
\multirow{2}{*}{$\begin{array}{c}\text { Jenis } \\
\text { Kelamin }\end{array}$} & Tuntutan Peran & 0.123 & Terima Ho & Tidak Ada Perbedaan \\
& Pribadi & 0.147 & Terima Ho & Tidak Ada Perbedaan \\
& Tantangan Individu & & & \\
& Tantangan Psikologi & 0.451 & Terima Ho & Tidak Ada Perbedaan \\
& Tantangan Organisasi & 0.862 & Terima Ho & Tidak Ada Perbedaan \\
\hline
\end{tabular}

Sikap karyawan berdasarkan usia menunjukkan tidak ada perbedaan sikap antara kelompok usia, seluruh karyawan PT. Bank Rakyat Indonesia (persero) Tbk Cabang Krekot mempunyai sikap menerima semua tuntutan dan tantangan dalam bekerja.

Tabel 6. Sikap responden berdasarkan usia

\begin{tabular}{clccc}
\hline Faktor & \multicolumn{1}{c}{ Kriteria } & $\begin{array}{c}\text { Tingkat } \\
\text { Signifikansi }\end{array}$ & Keputusan & Kesimpulan \\
& \multicolumn{1}{c}{ Tuntutan Kerja } & 0.124 & Terima Ho & Tidak Ada Perbedaan \\
& Tuntutan Peran & 0.858 & Terima Ho & Tidak Ada Perbedaan \\
& Tuntutan Hubungan Antar & 0.237 & Terima Ho & Tidak Ada Perbedaan \\
\multirow{2}{*}{ Usia } & Pribadi & & & \\
& Tantangan Individu & 0.076 & Terima Ho & Tidak Ada Perbedaan \\
& Tantangan Psikologi & 0.969 & Terima Ho & Tidak Ada Perbedaan \\
& Tantangan Organisasi & 0.055 & Terima Ho & Tidak Ada Perbedaan \\
\hline
\end{tabular}


Sikap karyawan berdasarkan unit kerja menunjukan tidak ada perbedaan sikap antara bagian marketing, SDM, dan operasional, seluruh karyawan PT. Bank Rakyat Indonesia (persero) Tbk Cabang Krekot menerima semua tuntutan dan tantangan dalam pekerjaan

Tabel 7. Sikap responden berdasarkan unit kerja

\begin{tabular}{clccl}
\hline Faktor & \multicolumn{1}{c}{ Kriteria } & $\begin{array}{c}\text { Tingkat } \\
\text { Signifikansi }\end{array}$ & Keputusan & Kesimpulan \\
& Tuntutan Kerja & 0.954 & Terima Ho & Tidak Ada Perbedaan \\
& Tuntutan Peran & 0.801 & Terima Ho & Tidak Ada Perbedaan \\
Unit & Tuntutan Hubungan Antar Pribadi & 0.248 & Terima Ho & Tidak Ada Perbedaan \\
Kerja & Tantangan Individu & 0.713 & Terima Ho & Tidak Ada Perbedaan \\
& Tantangan Psikologi & 0.652 & Terima Ho & Tidak Ada Perbedaan \\
& Tantangan Organisasi & 0.263 & Terima Ho & Tidak Ada Perbedaan \\
\hline
\end{tabular}

Sikap karyawan berdasarkan status pernikahan menunjukan tidak ada perbedaan sikap antara karyawan yang sudah menikah dengan yang belum menikah, seluruh karyawan PT. Bank Rakyat Indonesia (persero) Tbk Cabang Krekot menerima semua tuntutan dan tantangan dalam bekerja.

Tabel 8. Sikap responden berdasarkan status pernikahan

\begin{tabular}{clccc}
\hline \multicolumn{1}{c}{ Faktor } & \multicolumn{1}{c}{ Kriteria } & $\begin{array}{c}\text { Tingkat } \\
\text { Signifikansi }\end{array}$ & Keputusan & Kesimpulan \\
& Tuntutan Kerja & 0.526 & Terima Ho & Tidak Ada Perbedaan \\
& Tuntutan Peran & 0.316 & Terima Ho & Tidak Ada Perbedaan \\
Status & Tuntutan Hubungan Antar & 0.826 & Terima Ho & Tidak Ada Perbedaan \\
Pernikahan & Pribadi & & & \\
& Tantangan Individu & 0.298 & Terima Ho & Tidak Ada Perbedaan \\
& Tantangan Psikologi & 0.813 & Terima Ho & Tidak Ada Perbedaan \\
& Tantangan Organisasi & 0.079 & Terima Ho & Tidak Ada Perbedaan \\
\hline
\end{tabular}

Sikap karyawan berdasarkan masa kerja menunjukan adanya perbedaan sikap antara karyawan dengan masa kerja lebih lama atau senior dengan juniornya mengenai tuntutan kerja, tuntutan peran, dan tantangan individu. Karyawan dengan masa kerja lebih lama atau senior mempunyai tuntutan kerja, tuntutan peran, dan tantangan individu yang lebih besar daripada juniornya. Hal ini dikarenakan karyawan dengan masa kerja lebih lama atau senior harus mengajarkan hal-hal yang tidak diketahui tentang pekerjaan dan membimbing serta mengawasi pekerjaan juniornya sehingga mempunyai tantangan individu yang berbeda.

Tabel 9. Sikap responden berdasarkan masa kerja

\begin{tabular}{clccc}
\hline Faktor & \multicolumn{1}{c}{ Kriteria } & $\begin{array}{c}\text { Tingkat } \\
\text { Signifikansi }\end{array}$ & Keputusan & Kesimpulan \\
& Tuntutan Kerja & 0.000 & Tolak Ho & Ada Perbedaan \\
& Tuntutan Peran & 0.029 & Tolak Ho & Ada Perbedaan \\
Masa & Tuntutan Hubungan Antar Pribadi & 0.266 & Terima Ho & Tidak Ada Perbedaan \\
Kerja & Tantangan Individu & 0.041 & Tolak Ho & Ada Perbedaan \\
& Tantangan Psikologi & 0.089 & Terima Ho & Tidak Ada Perbedaan \\
& Tantangan Organisasi & 0.276 & Terima Ho & Tidak Ada Perbedaan \\
\hline
\end{tabular}


Sikap karyawan berdasarkan pendidikan terakhir menunjukan tidak ada perbedaan sikap antara karyawan dengan pendidikan terakhir D3, S1, dan S2, semua karyawan menerima tuntutan dan tantangan dalam bekerja.

Tabel 10. Sikap responden berdasarkan pendidikan

\begin{tabular}{clccc}
\hline Faktor & \multicolumn{1}{c}{ Kriteria } & $\begin{array}{c}\text { Tingkat } \\
\text { Signifikansi }\end{array}$ & Keputusan & Kesimpulan \\
\hline \multirow{2}{*}{ Pendidikan } & Tuntutan Kerja & 0.271 & Terima Ho & Tidak Ada Perbedaan \\
Terakhir & Tuntutan Peran & 0.326 & Terima Ho & Tidak Ada Perbedaan \\
& Tantangan Hubungan Antar Pribadi & 0.673 & Terima Ho & Tidak Ada Perbedaan \\
& Tantangan Psikologi & 0.602 & Terima Ho & Tidak Ada Perbedaan \\
& Tantangan Organisasi & 0.911 & Terima Ho & Tidak Ada Perbedaan \\
\hline
\end{tabular}

Sikap karyawan berdasarkan tempat tinggal menunjukan adanya perbedaan sikap antara karyawan yang belum mempunyai tempat tinggal dengan yang telah mempunyai tempat tinggal mengenai tantangan individu dan tantangan psikologi. Karyawan yang belum mempunyai tempat tinggal sendiri mempunyai tantangan individu dan psikologi yang lebih besar daripada yang telah memiliki tempat tinggal sehingga kinerja karwayan yang belum memiliki tempat tinggal berbeda dengan yang telah memiliki tempat tinggal.

Tabel 11. Sikap responden berdasarkan tempat tinggal

\begin{tabular}{clccc}
\hline Faktor & \multicolumn{1}{c}{ Kriteria } & $\begin{array}{c}\text { Tingkat } \\
\text { Signifikansi }\end{array}$ & Keputusan & Kesimpulan \\
& Tuntutan Kerja & 0.153 & Terima Ho & Tidak Ada Perbedaan \\
\multirow{2}{*}{ Tempat } & Tuntutan Peran & 0.612 & Terima Ho & Tidak Ada Perbedaan \\
Tinggal & Tuntutan Hubungan Antar Pribadi & 0.694 & Terima Ho & Tidak Ada Perbedaan \\
& TantanganIndividu & 0.001 & Tolak Ho & Ada Perbedaan \\
& Tantangan Psikologi & 0.028 & Tolak Ho & Ada Perbedaan \\
& Tantangan Organisasi & 0.211 & Terima Ho & Tidak Ada Perbedaan \\
\hline
\end{tabular}

\section{III.2. Analisis Rank Spearman}

Berdasarkan kategori penilaian koefisien korelasi yang dikemukakan oleh Sugiyono (2006), Tabel 12 di bawah ini menunjukan bahwa korelasi yang tertinggi adalah antara tuntutan peran dengan variabel organisasi memiliki hubungan yang sedang yaitu sebesar 0.401 dan korelasi yang terendah adalah antara tuntutan kerja dengan variabel organisasi yaitu sebesar -0.016 . Untuk sub variabel lainnya saling memiliki korelasi namun tingkat korelasinya rendah.

Tabel 12. Hasil analisis rank spearman antara variabel beban kerja dengan kinerja

\begin{tabular}{llccc}
\hline & Spearmans's rho & $\begin{array}{c}\text { Tantangan } \\
\text { Individu }\end{array}$ & $\begin{array}{c}\text { Tantangan } \\
\text { Psikologi }\end{array}$ & $\begin{array}{c}\text { Tantangan } \\
\text { Organisasi }\end{array}$ \\
\hline \multirow{3}{*}{ Tuntutan } & Correlation Coefficient & .041 & .094 & -.016 \\
Kerja & Sig. (2-tailed) & .648 & .293 & .860 \\
& $\mathrm{~N}$ & 127 & 127 & 127 \\
Tuntutan & Correlation Coefficient & .197 & .135 & .401 \\
Peran & Sig. (2-tailed) & .027 & .130 & .000 \\
\hline
\end{tabular}


42 |Adityawarman, Sanim, Sinaga - Pengaruh Beban Kerja terhadap Kinerja Karyawan

Lanjutan Tabel 12.

\begin{tabular}{llccc}
\hline \multicolumn{1}{c}{ Spearmans's rho } & $\begin{array}{c}\text { Tantangan } \\
\text { Individu }\end{array}$ & $\begin{array}{c}\text { Tantangan } \\
\text { Psikologi }\end{array}$ & $\begin{array}{c}\text { Tantangan } \\
\text { Organisasi }\end{array}$ \\
Tuntutan & Correlation Coefficient & .111 & .148 & .336 \\
Hubungan & Sig. (2-tailed) & .213 & .097 & .000 \\
Antar Pribadi & $\mathrm{N}$ & 127 & 127 & 127 \\
\hline
\end{tabular}

Hasil analisis antara variabel beban kerja dengan variabel kinerja tidak semuanya menunjukan hasil yang signifikan dikarenakan ada faktor lain yang menjadi penyebab tidak signifikannya hasil penelitian seperti variabel-variabel lain yang mempengaruhi yang tidak diteliti dalam penelitian ini misalnya motivasi, gaya kepemimpinan, dan lainnya.

\section{III.3. Metode Partial Least Square (PLS)}

Partial Least Square digunakan untuk mengetahui pengaruh beban kerja terhadap kinerja karyawan PT. Bank Rakyat Indonesia (persero) Tbk Cabang Krekot. Dari hasil analisis hipotesis tolak Ho dengan t hitung 13.45 lebih besar dari t-tabel 1.96, diketahui bahwa beban kerja berpengaruh positif dan signifikan secara langsung terhadap kinerja karyawan PT. Bank Rakyat Indonesia (persero) Tbk Cabang Krekot pada tingkat signifikansi $5 \%(p=0.10882)$ dengan kriteria goodness of fit. Kriteria tersebut dapat dilihat pada Tabel 3.

Tabel 13. Kriteria goodness of fit

\begin{tabular}{lccc}
\multicolumn{1}{c}{ Goodness-of-Fit } & Cut-off-Value & Hasil & Keterangan \\
\hline RMSEA (Root Mean square Error of Approximation) & $\leq 0.08$ & 0.08 & Good Fit \\
GFI(Goodness of Fit) & $\geq 0.90$ & 1.00 & Good Fit \\
CFI (Comparative Fit Index) & $\geq 0.90$ & 1.00 & Good Fit \\
NFI (Normed Fit Index) & $\geq 0.95$ & 0.99 & Good Fit \\
\hline
\end{tabular}

III.4. Implikasi Manajerial

Berdasarkan hasil yang didapat dari peneitian ini dan dikaitkan dengan teori dari Malik (2009) yang berpendapat bahwa penerapan strategi SDM yang tepat akan memunculkan kemampuan untuk mendorong proses kreasi praktik-praktik SDM yang lebih inovatif, progresif dan berkinerja tinggi, maka dibuatlah skala prioritas praktikpraktik SDM apa saja yang harus dilaksanakan dari hasil temuan berdasarkan koefisien korelasi dan signifikansi secara statistik dengan menggunakan metode Rank Spearman agar SDM PT. Bank Rakyat Indonesia (persero) Tbk Cabang Krekot lebih inovatif, progresif dan berkinerja tinggi.

Prioritas pertama adalah tuntutan peran. Tuntutan peran disini adalah berkaitan dengan tekanan yang diberikan kepada seseorang sebagai fungsi dari peran tertentu yang dimainkannya dalam organisasi. Konflik peran menciptakan ekspektasi yang mungkin sulit untuk diselesaikan atau dipenuhi, untuk itu perlu adanya sinkoronisasi antar karyawan agar konflik peran dapat dihindari dan bila mungkin dihilangkan. Penyempurnaan dapat dilakukan dengan cara saling mengenal peran masing-masing karyawan, dengan harapan setelah mengetahui dan mengerti peran dari rekan kerjannya maka konflik peran dapat di hindari sehingga permasalahan pekerjaan yang 
muncul dapat dicarikan solusinnya. Penyempurnaan pada aspek tuntutan peran dapat dilaksanakan pada Forum Peningkatan Kinerja (FPK) yang diadakan oleh PT. Bank Rakyat Indonesia (persero) Tbk Cabang Krekot secara periodik setiap tahunnya.

Prioritas kedua adalah tuntutan hubungan antar pribadi. Tuntutan hubungan antar pribadi adalah tekanan yang diciptakan karyawan lain, kurangnya dukungan sosial dari rekan-rekan, dan hubungan antar pribadi yang buruk dapat menimbulkan stres yang cukup besar. Untuk mengatasi permasalahan tersebut maka perlu ditingkatkan kembali budaya kekeluargaan yang memang selama ini ada di Bank Rakyat Indonesia. Tuntutan hubungan antar pribadi memang menjadi fokus, karena berkaitan dengan tingkat kerja sama antar individu baik vertikal maupun horizontal dan antar bagian. Meskipun demikian, penyempurnaan tetap diperlukan mengingat semakin banyak karyawan baru yang di rekrut oleh PT. Bank Rakyat Indonesia (persero) Tbk Cabang Krekot seiring dengan ekspansi bisnis yang semakin luas. Penyempurnaan dalam hubungan antar pribadi dapat dilakukan pada Forum Peningkatan Kinerja (FPK) yang dilaksanakan oleh PT. Bank Rakyat Indonesia (persero) Tbk Cabang Krekot setiap tahunnya.

Prioritas ketiga adalah tuntutan kerja. Tuntutan ini adalah tuntutan (demand) yang melebihi kemampuan dan dapat menimbulkan situasi tekanan di dalam diri individu. Terlebih, ketidakseimbangan tersebut diperburuk dengan adanya control atau kendali dari atasan di lokasi kerja. Kendali oleh atasan yang tidak mempertimbangkan aspek kemampuan seorang akan semakin meningkatkan tekanan atas diri seorang karyawan. Agar permasalahan tersebut dapat diatasi maka diperlukan suatu tes untuk mengukur kemampuan seorang karyawan dalam mengadapi tuntutan pekerjaan, sehingga atasan dapat mempertimbangkan kemampuan bawahannya untuk menyelesaikan pekerjaan. Pengukuran kemampuan seseorang ini diharapkan dapat menjadi salah satu agenda Forum Peningkatan Kinerja (FPK) yang dilaksanakan setiap tahun agar tekanan dalam diri karyawan dapat dikurangi dan bila mungkin dihilangkan.

\section{Kesimpulan}

Hasil analisis dari penelitian ini diperoleh beberapa simpulan, yaitu ada perbedaan sikap mengenai beban kerja dan kinerja berdasarkan jenis kelamin yaitu pada tantangan organisasi. Ada perbedaan sikap mengenai beban kerja dan kinerja berdasarkan masa kerja yaitu pada tuntutan kerja, tuntutan peran, dan tantangan individu. Ada perbedaan sikap mengenai beban kerja dan kinerja berdasarkan tempat tinggal yaitu pada tantangan individu dan tantangan psikologi. Korelasi beban kerja dengan kinerja menunjukkan bahwa korelasi yang tertinggi adalah antara tuntutan peran dengan variabel organisasi dan korelasi yang terendah adalah antara tuntutan kerja dengan variabel organisasi. Beban kerja berpengaruh positif dan signifikan secara langsung terhadap kinerja karyawan PT. Bank Rakyat Indonesia (persero) Tbk Cabang Krekot. 
44|Adityawarman, Sanim, Sinaga - Pengaruh Beban Kerja terhadap Kinerja Karyawan

\section{Daftar Pustaka}

Akbar A. 2013. Significance of human resource management in organizations: linking global pratices with local perspective. Journal of Arts, Science \& Commerce, 4(1): 78-87.

Bandar A, Manar AQ. 2012. The effect of human resource management practices on job involvement in selected private companies in Jordan. Canadian Social Science, 8(2): 50-57.

Cao X, Yu K. 2007. Human resources management problems and countermeasures in private enterprises. National Business (Economic Theory Studies), 1(1): 1-4.

Dollyono E. 2008. Analisis Korelasi Penilaian Kinerja dengan Komitmen Organisasi dan Kepuasan Kerja Pegawai Dinas PJU dan SJU DKI Jakarta [tesis]. Bogor (ID): Institut Pertanian Bogor.

Katefina V. 2013. Approaches to the term "appraisal" in the area of human resource management. Scientific Papers of the University of Pardubice, 1(1): 160-169.

Khadijeh KP, Sumangala C. 2013. Development of human resource accounting (HRA) research in the capital market: evidence from India. Golden Research Thoughts, 2(11): 1-4.

Malik N. 2009. Peran strategi sumber daya manusia terhadap kinerja pasar perusahaan perbankan di Indonesia. Jurnal Ekonomi Manajemen Sumber Daya, 10(1): 48-68.

Mangkuprawira S, Hubeis AV. 2007. Manajemen Mutu Sumber Daya Manusia. Jakarta (ID): Ghalia Indonesia.

[Menpan] Kementrian Pendayagunaan Aparatur Negara. 1997. Definisi Beban Kerja. [internet]. [diunduh 12 Oktober 2011]. Tersedia pada: http://www.bkn.go.id.

Nugroho BA. 2005. Strategi Jitu Memilih Metode Statistik Penelitian dengan SPSS. Edisi Pertama. Yogyakarta (ID): CV. Andi Offset

Pettijohn CE, Taylor AJ. 2000. Research note: an exploratory analysis of salesperson perceptions of the criteria used in performance appraisal, job satisfaction, and organizational commitment. Journal of Personal Selling and Sales Management, 20(2): 68-76.

Setyawan AA, Kuswati R. 2006. Teknologi informasi dan reposisi fungsi manajemen sumber daya manusia. Jurnal Manajemen dan Bisnis Benefit, 10(1): 109-116.

Simamora H. 2001. Manajemen Sumber Daya Manusia. Edisi ke-4. Yogyakarta (ID): STIE YKPN.

Sugiyono. 2006. Statistika Untuk Penelitian. Edisi ke-7. Bandung (ID): CVAlfabeta.

Umar H. 2002. Desain Penelitian MSDM dan perilaku karyawan. Jakarta (ID): Rajawali Pers 